\title{
Tumor Suppressor RIZ1 in Carcinogenesis
}

\section{Wanpeng Sun and Jian Yang*}

Drug Discovery and Development Research Group, College of Pharmacy and Nutrition, University of Saskatchewan, Canada

\begin{abstract}
Human retinoblastoma protein-interacting zinc-finger gene RIZ (PRDM2) encodes two protein products, tumor suppressor RIZ1 and proto-oncoprotein RIZ2, using alternative promoters. RIZ1 and RIZ2 regulate normal cell division in a Yin-Yang fashion with RIZ1 arresting cells in G2/M phase and inducing apoptosis and RIZ2 promoting cell proliferation. Silenced RIZ1 expression has been detected in various types of cancer. Because both RIZ isoforms contain multiple functional domains, their function mechanisms in suppressing or promoting tumor growth are complex. Based on the current knowledge, it is rational to propose four potential routes for RIZ1 to exert its tumor suppressing functions: directly repressing the promoters of growth factors such as insulin-like growth factor-1 via H3K9 (histone H3 lysine 9) methylation, regulating estrogen-induced pS2 transcription through forming a complex with transcriptional co-activator p300, activating tumor suppressor p53 using a methylation-acetylation interplay, and blocking gene transcriptions by binding to PR-Set7 and establishing a $\mathrm{H} 4 \mathrm{~K} 2 \mathrm{O}^{\mathrm{me}}$ (histone $\mathrm{H} 4$ lysine 20 monomethylation) - H3K9me1 (histone $\mathrm{H} 3$ lysine 9 mono-methylation) trans-tail 'histone code' at an ectopic locus.
\end{abstract}

Keywords: Tumor suppressor; Carcinogenesis; RIZ gene

\section{Introduction}

Human tumor suppressor RIZ1 (PRDM2) is encoded by the retinoblastoma protein-interacting zinc-finger gene RIZ (PRDM2), which was first identified from a functional screening for retinoblastoma tumor suppressor binding genes [1]. Gene RIZ is located on the distal short arm of human chromosome 1 (1q36.21), which also harbors other tumor suppressor genes such as CHD5. Besides RIZ1, gene RIZ encodes a second protein product, RIZ2, using an internal promoter other than the promoter that transcribes full-length RIZ mRNA [2-4]. Theoretically, it is possible to have other RIZ isoforms from alternative RNA splicing since gene RIZ contains more than 10 potential exons [3]. As shown in Figure 1, except for an N-terminal PR domain possessing histone methyltransferase (HMT) activity, RIZ1 and RIZ2 share the same amino acid sequences and both contain a Rb-binding domain, eight zinc finger motifs, a src homology 3 (SH3) domain, a putative GTPase domain, a proline-rich domain and a PR-binding motif (PRB). The expression level is almost identical between RIZ1 and RIZ2 among different human tissues except testes; and such an equivalent expression is essential for normal cell growth and functions $[2,5,6]$

\section{Silencing of RIZ1 during Carcinogenesis}

RIZ1 and RIZ2 regulate normal cell division and functions in a Yin-Yang fashion [2-4]. RIZ1 acts as tumor suppressor to arrest cells in the G2/M phase of cell cycle and induce cell apoptosis; whereas RIZ2 functions as a proto-oncoprotein to promote cell proliferation $[5,6]$. Silenced or decreased RIZ1 expression, commonly associated with normal or increased RIZ2 expression, has been detected in various types of cancer [1,3-36]. The silencing of RIZ1 expression is through at least one of the following four mechanisms:

\section{Methylation of the CpG islands in RIZ1 promoter}

This is the mostly studied mechanism, but identity of the enzyme that methylates RIZ1 promoter is still not clear. Aberrant methylation of RIZ1 promoter has been observed in different types of cancer (Table 1) $[4,7-27]$. Nevertheless, a pairwise analysis by Feng et al. did not find increased methylation of gene RIZ between normal and malignant breast tissues [37]. Recently, RIZ1 promoter was shown to be upregulated by silencing SMYD3 (SET and MYND domain-containing protein 3), a histone/protein methyltransferase, in human hepatoma [38] and down-regulated by silencing transcriptional repressor YY1 (Yin Yang 1) in human osteosarcoma [39]. Further studies are definitely warranted to understand how RIZ1 promoter is regulated by SMYD3, YY1, and even other histone/protein methyltransferases and transcriptional repressors

\section{Loss of heterozygosity (LOH) within the RIZ locus}

Gene RIZ is located on the short arm of chromosome 1 (1p36), which is unstable and frequently lost in human malignancies via nonrandom deletions [40-42]. LOH within the RIZ locus in different types of cancers has been summarized in Table 2 [18,23,28-31]. However, a recent review on five candidate tumor suppressor genes, CHD5, CAMTA1, KIF1B, CASZ1 and miR-34a, located on 1p36 showed that partial impairment instead of complete inactivation of their expression was enough to promote tumorigenesis [43], implicating that downregulation of gene $R I Z$ might follow the same mechanism in stimulating tumor development and growth.

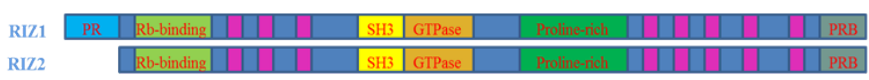

Figure 1: Structural components in tumor suppressor RIZ1 and its alternatively transcribed proto-oncoprotein RIZ2. Except the PR domain located at the $\mathrm{N}$-terminus of RIZ1, both RIZ isoforms containing a retinoblastoma-binding (Rb) domain, eight zinc finger motifs (shown in pink), a SH3 domain, a putative GTPase domain, a proline-rich region and a PR domain-binding motif (PRB).

*Corresponding author: Jian Yang, Drug Discovery and Development Research Group, College of Pharmacy and Nutrition, University of Saskatchewan, 107 Wiggins Road, Saskatoon, SK S7N 5E5, Canada, Tel: 306-966-6361; Fax: 306966-6377; E-mail: jian.yang@usask.ca

Received October 30, 2013; Accepted January 22, 2014; Published January 27, 2014

Citation: Sun W, Yang J (2014) Tumor Suppressor RIZ1 in Carcinogenesis. J Carcinog Mutagen 5: 160. doi:10.4172/2157-2518.1000160

Copyright: ( $\odot 2014$ Sun W, et al. This is an open-access article distributed under the terms of the Creative Commons Attribution License, which permits unrestricted use, distribution, and reproduction in any medium, provided the original author and source are credited. 


\begin{tabular}{|c|c|c|c|}
\hline Cancer type & $\begin{array}{l}\text { Sample } \\
\text { size }\end{array}$ & Promoter methylation & References \\
\hline Liver cancer & $\begin{array}{l}32 \\
42 \\
48 \\
60 \\
39 \\
42\end{array}$ & $\begin{array}{l}62 \%(20 / 32) \\
79 \%(33 / 42) \\
67 \%(32 / 48) \\
62 \%(37 / 60) \\
56 \%(22 / 39) \\
45 \%(20 / 42)\end{array}$ & $\begin{array}{c}{[4]} \\
{[7]} \\
{[8]} \\
{[9]} \\
{[10]} \\
{[11]}\end{array}$ \\
\hline Neuroblastoma & 33 & $<10 \%$ & [12] \\
\hline Breast cancer & 25 & $44 \%(11 / 25)$ & [4] \\
\hline Colorectal cancer & 38 & $16 \%(6 / 38)$ (high-level MSI) & [13] \\
\hline Ovarian cancer & $\begin{array}{l}89 \\
69\end{array}$ & $\begin{array}{c}22 \%(20 / 89) \\
7 \%(5 / 69)\end{array}$ & $\begin{array}{l}{[14]} \\
{[15]}\end{array}$ \\
\hline Gastric cancer & $\begin{array}{l}75 \\
45 \\
30\end{array}$ & $\begin{array}{l}67 \%(50 / 75) \\
69 \%(31 / 45) \\
37 \%(11 / 30)\end{array}$ & $\begin{array}{l}{[16]} \\
{[17]} \\
{[18]}\end{array}$ \\
\hline Prostate cancer & $\begin{array}{c}47 \\
101\end{array}$ & $\begin{array}{c}43 \%(20 / 47) \\
31 \%(31 / 101)\end{array}$ & $\begin{array}{l}{[19]} \\
{[20]}\end{array}$ \\
\hline Thyroid cancer & 19 & $100 \%(19 / 19)$ & [21] \\
\hline Cervical cancer & 40 & $38 \%(14 / 40)$ & [22] \\
\hline Parathyroid cancer & 47 & $36 \%(17 / 37)$ & [23] \\
\hline Malignant pheochromocytoma & 4 & $50 \%(2 / 4)$ & [23] \\
\hline Nasopharyngeal carcinoma & $\begin{array}{l}30 \\
53\end{array}$ & $\begin{array}{l}60 \%(18 / 30) \\
57 \%(30 / 53)\end{array}$ & $\begin{array}{l}{[24]} \\
{[25]}\end{array}$ \\
\hline Acute lymphoblastic leukemia & $\begin{array}{l}71 \\
72\end{array}$ & $\begin{array}{c}16 \%(\mathrm{~T}: 64 \%, \mathrm{~B}: 7 \%) \\
31 \%(22 / 72)\end{array}$ & $\begin{array}{l}{[26]} \\
{[27]}\end{array}$ \\
\hline
\end{tabular}

Table 1: RIZ1 promoter methylation in various types of cancer.

\begin{tabular}{|l|c|c|c|}
\hline Cancer type & Sample size & LOH within $R I Z$ locus & References \\
\hline Parathyroid cancer & 47 & $28 \%(13 / 47)$ & {$[23]$} \\
\hline Pheochromocytoma & 23 & $39 \%(9 / 23)$ & {$[23]$} \\
\hline Liver cancer & 79 & $39 \%(31 / 79)$ & {$[28]$} \\
\hline Colon cancer & 47 & $23 \%(11 / 47)$ & {$[28]$} \\
\hline Breast cancer & 43 & $19 \%(8 / 43)$ & {$[28]$} \\
\hline Gastric cancer & 66 & $12 \%(8 / 66)$ & {$[28]$} \\
\hline Oral squamous cell & 30 & $33 \%(10 / 30)$ & {$[18]$} \\
\hline carcinoma & 27 & $33 \%(9 / 27)$ & {$[29]$} \\
\hline Neuroblastoma & 122 & $26 \%(32 / 122)$ & {$[30]$} \\
\hline Melanoma & 57 & $18 \%(10 / 57)$ & {$[31]$} \\
\hline
\end{tabular}

Table 2: $\mathrm{LOH}$ within the RIZ locus in various types of cancer.

\section{Mutations within the RIZ gene}

Both missense and frameshift mutations in RIZ have been observed in human cancers [18,32-35]. Frameshift mutations were detected in gene $R I Z$ at two poly- $\mathrm{A}$ tracts, $\mathrm{A}_{8}$ and $\mathrm{A}_{9}$, within the coding region in gastric, pancreatic, colorectal and endometrial cancers [18,32-34]. Both mutations end up with truncated RIZ proteins (both RIZ1 and RIZ2) without the C-terminal PRB motif, which in turn may disrupt the YinYang regulation of normal cell functions and lead to carcinogenesis due to eliminated PR-PRB interaction although this interaction has not yet been confirmed by any in vivo study. Searching for missense mutations in RIZ has been focused on the PR domain and its immediate C-terminal neighboring region. Missense mutation A563G (corresponding to amino acid Ile188Val mutation) happened in high incidence $(29 \%, 11 / 35)$ in diffuse large B-cell lymphoma instead of other types of cancer [35]. Missense mutations G317A (corresponding to amino acid Cys106Tyr mutation) and C476T (corresponding to amino acid Ala159Val mutation) were identified in human osteosarcoma cell line Saos2 and neuroblastoma cell line SMS-KCNR, respectively [35].

\section{Down-regulation via histone $\mathrm{H} 3$ lysine 9 (H3K9) methylation}

This is the least studied mechanism on silencing RIZ1 expression.
A previous study by Zhang et al. showed extensive $\mathrm{H} 3 \mathrm{~K}^{\mathrm{me}}{ }^{3}$ (H3K9 trimethylation) at the silenced $R I Z 1$ promoter in human hepatocellular carcinoma cell line HepG2 [8]. As RIZ1 possesses H3K9 methylation activity, an interesting issue needs to be further addressed is whether there is a negative feedback on RIZ1 expression, i.e., RIZ1 methylates $\mathrm{H} 3 \mathrm{~K} 9$ at its own promoter region. Reintroduction of RIZ1 via viral transfection was shown to suppress proliferation, arrest cell cycle in G2/M phase and induce apoptosis in cancer cells [44,45]. Furthermore, the expression level of RIZ1 has been related to tumor metastasis. Dong et al. reported that reduced RIZ1 expression was correlated positively with increased risk of tumor metastasis [46]; however, Sun et al. showed that RIZ1 mRNA expression was increased significantly at stage IV in various types of cancer [47]. Since patient survival rate drops dramatically for all types of cancer when tumor cells metastasize to distal organs, it is extremely important in future studies to identify whether RIZ1 expression is indeed increased at protein level as increases in mRNA expression do not always translate proportionally into protein expression, whether RIZ1 is in the wild-type or mutated form, and what role RIZ1 plays during metastasis, i.e., increased RIZ1 expression in late-stage diseases promotes metastasis due to local stress resulted from increased tumor mass and reduced oxygen and nutrient supplies or counteracts tumor metastasis as a self-protective yet unsuccessful endeavour.

\section{Structural Components and Their Biological Functions}

Since RIZ contains multiple functional domains, its biological function is deemed to be complex. Studying its structural components (Figure 1) as well as their individual biological functions will definitely provide us a better understanding of RIZ1. The PR domain, which is located at the N-terminus of RIZ1 and the only structural difference between the two RIZ isoforms, possesses HMT activity and is structurally related to the suppressor of variegation-enhancer of zeste-trithorax (SET) domain of chromatin-associated proteins involved in gene expressions [48]. H3K9 methylation by RIZ1 is via the function of the PR domain $[48,49]$. The ability of RIZ1 to methylate H3K9 was depleted by the Ile188V mutation and decreased by the Cys106Tyr and Ala159Val mutations [49]. Transfection with cDNA encoding only the PR domain and its C-terminal neighboring region (amino acid residues 13-190) of RIZ1 significantly increased the cell death of hepatoma HuH7 cells, implicating that the PR domain possesses tumor suppressing activity even without the help of the other functional domains $[47,50]$. The Rb-binding domain interacts with the C-terminus of retinoblastoma protein $(\mathrm{Rb})$, which is an important tumor suppressor [51].Since $\mathrm{Rb}$ is a common target for viral oncoproteins, it has been speculated that oncoviral proteins may structurally mimic RIZ proteins (RIZ1 and RIZ2) to interact with $\mathrm{Rb}$ and alter its biological function [51]. Extensive orthology is revealed between the Rb-binding domain of RIZ proteins and adenovirus oncoprotein E1A, which promotes cell proliferation, although they are evolutionally unrelated [51,52]. Eight zinc finger motifs are dispersed throughout the central and C-terminal regions of RIZ proteins. Zinc fingers 1-6 are $\mathrm{C} 2-\mathrm{H} 2$ type and zinc fingers 7-8 are $\mathrm{C} 2-\mathrm{HC}$ type [51]. The $\mathrm{C} 2-\mathrm{H} 2$ type zinc fingers are usually involved in transcriptional regulation; whereas the $\mathrm{C} 2-\mathrm{HC}$ type zinc fingers inhibit cell apoptosis [53]. In spite of that the functions of zinc fingers 4-8 remain unclear, zinc fingers 1-3 were shown to be essential for DNA binding [54]. Transfection and expression of these three zinc fingers increased cell proliferation in breast cancer cells [55]. Homology has been observed between the zinc fingers of RIZ proteins and the zinc fingers of 
other PR-domain containing proteins [51]. RIZ proteins contain a putative GTPase domain [54]. Both RIZ1 and RIZ2 can suppress the transcription of a herpes simplex virus thymidine kinase promoter [54]. A point mutation (Lys755Asn) in the GTPase domain disrupted its GTPase activity but did not change the transcriptional repression action of the RIZ proteins [54]. Interestingly, the SH3 domain, which is located immediately N-terminal to the GTPase domain, was involved in this repression action as revealed by point mutation studies [54]. The SH3 domain helps in assembling protein complexes via binding to proline-rich peptides [56]. RIZ proteins also contain a proline-rich region; however, it is unknown whether there is an interaction between the SH3 domain and the proline-rich region. The LXXLL motif in the proline-rich region is essential to receive estrogen receptor signaling and change the distribution of RIZ proteins inside cells [57]. The C-terminal PR-domain binding (PRB) motif was revealed from an in vitro assay [58]; however the interaction between $\mathrm{PR}$ and $\mathrm{PRB}$ has not yet been observed under in vivo conditions. The important YinYang regulation roles played by the RIZ proteins during carcinogenesis warrant further investigations on how these functional domains coordinate together to fulfil the tumor-suppressing function for RIZ1 and tumorigenic action for RIZ2.

\section{Functional Mechanism}

Contrary to the large amount of information on silencing RIZ1 expression during carcinogenesis, little is known about the functional mechanisms of RIZ1, RIZ2 and their Yin-Yang regulations under in vivo conditions. The very limited research on the functional mechanism of RIZ1 has been focused on its HMT activity since PR domain is the only structural difference between RIZ1 and RIZ2. Furthermore, histone modification is closely related to DNA methylation [59]. Histone modification undergoes a dramatic change from $\mathrm{H} 3^{\mathrm{Ac}}$ (histone $\mathrm{H} 3$ acetylation), $\mathrm{H} 4^{\mathrm{Ac}}$ (histone $\mathrm{H} 4$ acetylation) and $\mathrm{H} 3 \mathrm{~K} 4^{\mathrm{me} 2 / 3}$ (histone H3 lysine 4 di- or tri-methylation) in normal cells with un-methylated $\mathrm{CpG}$ islands to $\mathrm{H}_{3} \mathrm{~K}^{\text {me2/3 }}$ (histone $\mathrm{H} 3$ lysine 9 di- or tri-methylation) and/or $\mathrm{H} 3 \mathrm{~K}_{2} 7^{\mathrm{me} 3}$ (histone $\mathrm{H} 3$ lysine 27 di- or tri-methylation) in cancer cells with aberrant methylation of the CpG islands [59-61]. Based on the limited information on the functions of RIZ1, it is still rational to propose the following four potential regulatory routes to explain the tumor suppressing and anti-metastasis functions of RIZ1 (Figure 2).

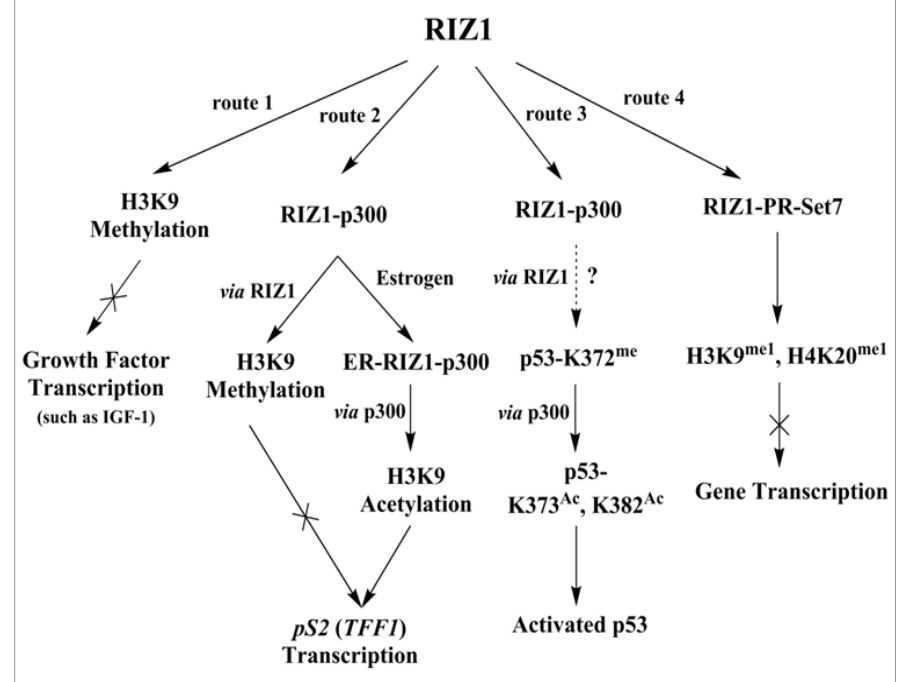

Figure 2: Four potential regulatory routes for the tumor-suppressing and antimetastasis functions of RIZ1.

\section{RIZ1 directly represses the promoters of growth factors involved in carcinogenesis via $\mathrm{H} 3 \mathrm{~K} 9$ methylation}

This route is proposed based on the observation that RIZ1 suppressed the insulin-like growth factor-1 (IGF-1) signaling pathway by directly repressing the IGF-1 promoter via $\mathrm{H} 3 \mathrm{~K} 9$ methylation in chronic myeloid leukemia [45].The promoter repression would, in turn, reduce the transcription level of the growth factors and attenuate their downstream signaling.

\section{RIZ1 exerts its histone modification functions via binding to p300}

RIZ1 was observed to form a complex with transcriptional coactivator p300 to augment estrogen-induced transcription of gene pS2 (TFF1) in human breast cancer MCF7 cells [62]. Gene pS2 (TFF1) encodes a small protease-resistant secretory protein TFF1 (trefoil factor 1), which acts as a tumor suppressor in gastric cancer $[63,64]$ but a tumorigenesis and metastasis promoter in prostate and pancreatic cancers [65-67]. The role TFF1 plays in breast cancer is controversial. Amiry et al. showed that TFF1 functioned as an oncogene and forced expression of TFF1 increased the oncogenicity of human breast cancer MCF7 and T47D cells [68]. On the contrary, Buache et al. reported TFF1 acted as a beneficial factor rather than an oncogene in the breast and knockout of TFF 1 augmented the tumorigenicity of breast cancer cells and stimulated breast tumor development [69]. Although TFF1 enhanced the migration and invasion of breast cancer MDA-MB-231, MCF7 and ZR75.1 cells under in vitro conditions, its expression is usually depleted in highly metastatic breast cancer cell lines such as MDA-MB-231 [69]. A simple working model on how RIZ1 affects the estrogen-induced $p S 2$ transcription has been proposed taking in consideration that the RIZ1-p300 complex possesses both histone methylation and acetylation activities [62,70]. The complex methylates H3K9 via the HMT activity of RIZ1 and silences the $p S 2$ promoter in the absence of estrogen. Upon estrogen activation, the complex binds to the estrogen receptor (ER), switches the histone modification from $\mathrm{H} 3 \mathrm{~K} 9$ methylation to $\mathrm{H} 3 \mathrm{~K} 9$ acetylation via the histone acetyltransferase (HAT) activity of $\mathrm{p} 300$, and promotes $p S 2$ transcription. The delicate H3K9 modification by RIZ1-p300 may be essential in controlling the expression level of TFF1 and its biological function.

\section{RIZ1 expresses its tumor suppressing activity via tumor suppressor p53}

The expression of p53 was increased by RIZ1 in monocytic leukemia and malignant meningioma [71-73]. However, the exact mechanism is unknown. A previous study on p53 towards DNA damage showed a methylation-acetylation interplay was important for its activation and stabilization [74]. Set7/9, which possesses HMT activity at H3K4, methylated p53 at residue Lys372 [74]. Lys $372^{\text {me }}$ then activated p53 via enhancing its acetylation at residues Lys373 and Lys382 by p300 [74]. The methylation-acetylation interplay also increased the acetylation of histone 4 at the promoter region of tumor suppressor p21, leading to its up-regulation to suppress cell cycle [74-76]. Here, we hypothesize that the RIZ1-p300 complex activated p53 using a similar methylationacetylation interplay mechanism, i.e., RIZ1 could methylate Lys 372 of p53. Subsequently, the activated p53 can decrease tumor metastasis via CD82 [76-79]. In addition, the RIZ1-p300 complex might counteract the inhibitory effect of $\mathrm{Mdm} 2$ (mouse double minute 2 homolog) on p53 acetylation. 


\section{RIZ1 shows its tumor suppressing activity through direct binding to PR-Set7}

A very recent study by Congdon et al. showed that RIZ1 was recruited to chromatin by PR-Set7 via direct binding of their C-terminal domains [80]. The RIZ1-PR-Set7 complex was able to establish an $\mathrm{H} 4 \mathrm{~K}^{\mathrm{m}} \mathrm{m}^{\mathrm{mel}}-\mathrm{H} 3 \mathrm{~K}^{\mathrm{mel}}$ trans-tail 'histone code' at an ectopic locus to repress gene transcriptions [80]. Regardless of which route/routes RIZ1 may use to carry out its tumor suppressing functions, it is still unknown how the different functional domains of RIZ proteins coordinate one another during tumor-suppressing by RIZ1 or carcinogenesis by RIZ2. It will definitely be a big boost of our understanding about RIZ1 as well as other tumor suppressors if the coordination of these functional domains is clearly elucidated.

\section{References}

1. Buyse IM, Takahashi El, Huang S (1996) Physical mapping of the retinoblastoma interacting zinc finger gene RIZ to D1S228 on chromosome 1p36. Genomics 34: 119-121.

2. Liu L, Shao G, Steele-Perkins G, Huang S (1997) The retinoblastoma interacting zinc finger gene RIZ produces a PR domain-lacking product through an internal promoter. J Biol Chem 272: 2984-2991.

3. Jiang GL, Huang S (2000) The yin-yang of PR-domain family genes in tumorigenesis. Histol Histopathol 15: 109-117.

4. Du Y, Carling T, Fang W, Piao Z, Sheu JC, et al. (2001) Hypermethylation in human cancers of the RIZ1 tumor suppressor gene, a member of a histone/ protein methyltransferase superfamily. Cancer Res 61: 8094-8099.

5. He L, Yu JX, Liu L, Buyse IM, Wang MS, et al. (1998) RIZ1, but not the alternative RIZ2 product of the same gene, is underexpressed in breast cancer, and forced RIZ1 expression causes G2-M cell cycle arrest and/or apoptosis. Cancer Res 58: 4238-4244.

6. Jiang GI, Liu L, Buyse IM, Simon D, Huang S (1999) Decreased RIZ1 expression but not RIZ2 in hepatoma and suppression of hepatoma tumorigenicity by RIZ1. Int J Cancer 83: 541-546.

7. Formeister EJ, Tsuchiya M, Fujii H, Shpyleva S, Pogribny IP, et al. (2010) Comparative analysis of promoter methylation and gene expression endpoints between tumorous and non-tumorous tissues from HCV-positive patients with hepatocellular carcinoma. Mutat Res 692: 26-33.

8. Zhang C, Li H, Wang Y, Liu W, Zhang Q, et al. (2010) Epigenetic inactivation of the tumor suppressor gene RIZ1 in hepatocellular carcinoma involves both DNA methylation and histone modifications. J Hepatol 53: 889-895.

9. Lou C, Du Z, Yang B, Gao Y, Wang Y, et al. (2009) Aberrant DNA methylation profile of hepatocellular carcinoma and surgically resected margin. Cancer Sci 100: $996-1004$

10. Piao GH, Piao WH, He Y, Zhang HH, Wang GQ, et al. (2008) Hyper-methylation of RIZ1 tumor suppressor gene is involved in the early tumorigenesis of hepatocellular carcinoma. Histol Histopathol 23: 1171-1175.

11. Nomoto S, Kinoshita T, Kato K, Otani S, Kasuya H, et al. (2007) Hypermethylation of multiple genes as clonal markers in multicentric hepatocellular carcinoma. $\mathrm{Br}$ J Cancer 97: 1260-1265.

12. Geli J, Kiss N, Kogner P, Larsson C (2010) Suppression of RIZ in biologically unfavourable neuroblastomas. Int J Oncol 37: 1323-1330.

13. Whitehall VL, Wynter CV, Walsh MD, Simms LA, Purdie D, et al. (2002) Morphological and molecular heterogeneity within nonmicrosatellite instabilityhigh colorectal cancer. Cancer Res 62: 6011-6014.

14. Tam KF, Liu VW, Liu SS, Tsang PC, Cheung AN, et al. (2007) Methylation profile in benign, borderline and malignant ovarian tumors. J Cancer Res Clin Oncol 133: 331-341.

15. Akahira J, Suzuki F, Suzuki T, Miura I, Kamogawa N, et al. (2007) Decreased expression of RIZ1 and its clinicopathological significance in epithelial ovarian carcinoma: correlation with epigenetic inactivation by aberrant DNA methylation. Pathol Int 57: 725-733.

16. Oue N, Mitani Y, Motoshita J, Matsumura S, Yoshida K, et al. (2006) Accumulation of DNA methylation is associated with tumor stage in gastric cancer. Cancer 106: 1250-1259.
17. Oshimo Y, Oue N, Mitani Y, Nakayama H, Kitadai Y, et al. (2004) Frequent epigenetic inactivation of RIZ1 by promoter hypermethylation in human gastric carcinoma. Int J Cancer 110: 212-218.

18. Tokumaru $Y$, Nomoto $S$, Jerónimo C, Henrique R, Harden S, et al. (2003) Biallelic inactivation of the RIZ1 gene in human gastric cancer. Oncogene 22: 6954-6958.

19. Hasegawa Y, Matsubara A, Teishima J, Seki M, Mita K, et al. (2007) DNA methylation of the RIZ1 gene is associated with nuclear accumulation of p53 in prostate cancer. Cancer Sci 98: 32-36.

20. Suzuki M, Shigematsu H, Shivapurkar N, Reddy J, Miyajima K, et al. (2006) Methylation of apoptosis related genes in the pathogenesis and prognosis of prostate cancer. Cancer Lett 242: 222-230.

21. Lal G, Padmanabha L, Smith BJ, Nicholson RM, Howe JR, et al. (2006) RIZ1 is epigenetically inactivated by promoter hypermethylation in thyroid carcinoma. Cancer 107: 2752-2759.

22. Cheng HY, Gao Y, Lou G (2010) DNA methylation of the RIZ1 tumor suppressor gene plays an important role in the tumorigenesis of cervical cancer. Eur $\mathrm{J}$ Med Res 15: 20-24.

23. Carling T, Du Y, Fang W, Correa P, Huang S (2003) Intragenic allelic loss and promoter hypermethylation of the RIZ1 tumor suppressor gene in parathyroid tumors and pheochromocytomas. Surgery 134: 932-939.

24. Chang HW, Chan A, Kwong DL, Wei WI, Sham JS, et al. (2003) Detection of hypermethylated RIZ1 gene in primary tumor, mouth, and throat rinsing fluid, nasopharyngeal swab, and peripheral blood of nasopharyngeal carcinoma patient. Clin Cancer Res 9: 1033-1038.

25. Hutajulu SH, Indrasari SR, Indrawati LP, Harijadi A, Duin S, et al. (2011) Epigenetic markers for early detection of nasopharyngeal carcinoma in a high risk population. Mol Cancer 10: 48.

26. Shimura H, Mori N, Wang YH, Okada M, Motoji T (2012) Aberrant methylation and decreased expression of the RIZ1 gene are frequent in adult acute lymphoblastic leukemia of T-cell phenotype. Leuk Lymphoma 53: 1599-1609.

27. Mori N, Yoshinaga K, Tomita K, Ohwashi M, Kondoh T, et al. (2011) Aberrant methylation of the RIZ1 gene in myelodysplastic syndrome and acute myeloid leukemia. Leuk Res 35: 516-521.

28. Fang W, Piao Z, Buyse IM, Simon D, Sheu JC, et al. (2001) Preferential loss of a polymorphic RIZ allele in human hepatocellular carcinoma. $\mathrm{Br} \mathrm{J}$ Cancer 84: 743-747.

29. Lefeuvre M, Gunduz M, Nagatsuka H, Gunduz E, Al Sheikh Ali M, et al. (2009) Fine deletion analysis of 1 p36 chromosomal region in oral squamous cell carcinomas. J Oral Pathol Med 38: 94-98.

30. White PS, Maris JM, Beltinger C, Sulman E, Marshall HN, et al. (1995) A region of consistent deletion in neuroblastoma maps within human chromosome 1p36.2-36.3. Proc Natl Acad Sci U S A 92: 5520-5524.

31. Taback B, Fujiwara Y, Wang HJ, Foshag LJ, Morton DL, et al. (2001) Prognostic significance of circulating microsatellite markers in the plasma of melanoma patients. Cancer Res 61: 5723-5726.

32. Chadwick RB, Jiang GL, Bennington GA, Yuan B, Johnson CK, et al. (2000) Candidate tumor suppressor RIZ is frequently involved in colorecta carcinogenesis. Proc Natl Acad Sci U S A 97: 2662-2667.

33. Piao Z, Fang W, Malkhosyan S, Kim H, Horii A, et al. (2000) Frequent frameshift mutations of RIZ in sporadic gastrointestinal and endometrial carcinomas with microsatellite instability. Cancer Res 60: 4701-4704.

34. Sakurada K, Furukawa T, Kato Y, Kayama T, Huang S, et al. (2001) RIZ, the retinoblastoma protein interacting zinc finger gene, is mutated in genetically unstable cancers of the pancreas, stomach, and colorectum. Genes Chromosomes Cancer 30: 207-211.

35. Steele-Perkins G, Fang W, Yang XH, Van Gele M, Carling T, et al. (2001) Tumor formation and inactivation of RIZ1, an Rb-binding member of a nuclear protein-methyltransferase superfamily. Genes Dev 15: 2250-2262.

36. Lakshmikuttyamma A, Takahashi N, Pastural E, Torlakovic E, Amin HM, et al. (2009) RIZ1 is potential CML tumor suppressor that is down-regulated during disease progression. J Hematol Oncol 2: 28.

37. Feng W, Shen L, Wen S, Rosen DG, Jelinek J, et al. (2007) Correlation between CpG methylation profiles and hormone receptor status in breast cancers. Breast Cancer Res 9: R57. 
38. Chen LB, Xu JY, Yang Z, Wang GB (2007) Silencing SMYD3 in hepatoma demethylates RIZI promoter induces apoptosis and inhibits cell proliferation and migration. World J Gastroenterol 13: 5718-5724.

39. Abbondanza C, de Nigris F, De Rosa C, Rossiello R, Puca GA, et al. (2008) Silencing of YY1 downregulates RIZ1 promoter in human osteosarcoma. Oncol Res 17: 33-41.

40. Bagchi A, Mills AA (2008) The quest for the 1 p36 tumor suppressor. Cancer Res 68: 2551-2556.

41. Callaghan KA, Becker TE, Ellsworth DL, Hooke JA, Ellsworth RE, et al. (2007) Genomic instability and the development of metastatic lymph node tumors. Ann Surg Oncol 14: 3125-3132.

42. Hogarty MD, Maris JM, White PS, Guo C, Brodeur GM (2001) Analysis of genomic imprinting at 1p35-36 in neuroblastoma. Med Pediatr Oncol 36: 52-55.

43. Henrich KO, Schwab M, Westermann F (2012) 1p36 tumor suppression--a matter of dosage? Cancer Res 72: 6079-6088.

44. Jiang GL, Huang S (2001) Adenovirus expressing RIZ1 in tumor suppressor gene therapy of microsatellite-unstable colorectal cancers. Cancer Res 61 : 1796-1798.

45. Pastural E, Takahashi N, Dong WF, Bainbridge M, Hull A, et al. (2007) RIZ1 repression is associated with insulin-like growth factor- 1 signaling activation in chronic myeloid leukemia cell lines. Oncogene 26: 1586-1594.

46. Dong SW, Zhang P, Liu YM, Cui YT, Wang S, et al. (2012) Study on RIZ1 gene promoter methylation status in human esophageal squamous cell carcinoma. World J Gastroenterol 18: 576-582.

47. Sun W, Qiao L, Liu Q, Chen L, Ling B, et al. (2011) Anticancer activity of the PR domain of tumor suppressor RIZ1. Int J Med Sci 8: 161-167.

48. Kim KC, Huang S (2003) Histone methyltransferases in tumor suppression. Cancer Biol Ther 2: 491-499.

49. Kim KC, Geng L, Huang S (2003) Inactivation of a histone methyltransferase by mutations in human cancers. Cancer Res 63: 7619-7623.

50. Sun W, Geyer CR, Yang J (2008) Cloning, expression, purification and crystallization of the PR domain of human retinoblastoma protein-binding zinc finger protein 1 (RIZ1). Int J Mol Sci 9: 943-950.

51. Buyse IM, Shao G, Huang S (1995) The retinoblastoma protein binds to RIZ, a zinc-finger protein that shares an epitope with the adenovirus E1A protein. Proc Natl Acad Sci U S A 92: 4467-4471.

52. Parada C, Hernández Losa J, Guinea J, Sánchez-Arévalo V, Fernández Soria $\checkmark$, et al. (2003) Adenovirus E1a protein enhances the cytotoxic effects of the herpes thymidine kinase-ganciclovir system. Cancer Gene Ther 10: 152-160.

53. Krishna SS, Majumdar I, Grishin NV (2003) Structural classification of zinc fingers: survey and summary. Nucleic Acids Res 31: 532-550.

54. Xie M, Shao G, Buyse IM, Huang S (1997) Transcriptional repression mediated by the PR domain zinc finger gene RIZ. J Biol Chem 272: 26360-26366.

55. Rossi M, Abbondanza C, D’Arcangelo A, Gazzerro P, Medici N, et al. (2004) The Zn-finger domain of RIZ protein promotes MCF-7 cell proliferation. Cancer Lett 215: 229-237.

56. Morton CJ, Campbell ID (1994) SH3 domains. Molecular 'Velcro'. Curr Biol 4: 615-617.

57. Abbondanza C, Medici N, Nigro V, Rossi V, Gallo L, et al. (2000) The retinoblastoma-interacting zinc-finger protein $\mathrm{RIZ}$ is a downstream effector of estrogen action. Proc Natl Acad Sci U S A 97: 3130-3135.

58. Huang S, Shao G, Liu L (1998) The PR domain of the Rb-binding zinc finger protein RIZ1 is a protein binding interface and is related to the SET domain functioning in chromatin-mediated gene expression. J Biol Chem 273: 1593315939

59. McCabe MT, Brandes JC, Vertino PM (2009) Cancer DNA methylation: molecular mechanisms and clinical implications. Clin Cancer Res 15: 3927 3937.

60. Jenuwein T, Allis CD (2001) Translating the histone code. Science 293: 10741080.
61. Wang GG, Allis CD, Chi P (2007) Chromatin remodeling and cancer, Part I: Covalent histone modifications. Trends Mol Med 13: 363-372.

62. Carling T, Kim KC, Yang XH, Gu J, Zhang XK, et al. (2004) A histone methyltransferase is required for maximal response to female sex hormones. Mol Cell Biol 24: 7032-7042.

63. Feng G, Zhang Y, Yuan H, Bai R, Zheng J, et al. (2014) DNA methylation of trefoil factor 1 (TFF1) is associated with the tumorigenesis of gastric carcinoma. Mol Med Rep 9: 109-117.

64. Soutto M, Belkhiri A, Piazuelo MB, Schneider BG, Peng D, et al. (2011) Loss of TFF1 is associated with activation of NF-KB-mediated inflammation and gastric neoplasia in mice and humans. J Clin Invest 121: 1753-1767.

65. Radiloff DR, Wakeman TP, Feng J, Schilling S, Seto E, et al. (2011) Trefoi factor 1 acts to suppress senescence induced by oncogene activation during the cellular transformation process. Proc Natl Acad Sci U S A 108: 6591-6596.

66. Bougen NM, Amiry N, Yuan Y, Kong XJ, Pandey V, et al. (2013) Trefoil factor 1 suppression of E-CADHERIN enhances prostate carcinoma cell invasiveness and metastasis. Cancer Lett 332: 19-29.

67. Arumugam T, Brandt W, Ramachandran V, Moore TT, Wang H, et al. (2011) Trefoil factor 1 stimulates both pancreatic cancer and stellate cells and increases metastasis. Pancreas 40: 815-822.

68. Buache E, Etique N, Alpy F, Stoll I, Muckensturm M, et al. (2011) Deficiency in trefoil factor 1 (TFF1) increases tumorigenicity of human breast cancer cells and mammary tumor development in TFF1-knockout mice. Oncogene 30 3261-3273.

69. Amiry N, Kong X, Muniraj N, Kannan N, Grandison PM, et al. (2009) Trefoi factor-1 (TFF1) enhances oncogenicity of mammary carcinoma cells. Endocrinology 150: 4473-4483.

70. Hohenauer T, Moore AW (2012) The Prdm family: expanding roles in stem cells and development. Development 139: 2267-2282.

71. Noman AS, Koide N, Iftakhar-E-Khuda I, Dagvadorj J, Tumurkhuu G, et al. (2010) Retinoblastoma protein-interacting zinc finger 1, a tumor suppressor augments lipopolysaccharide-induced proinflammatory cytokine production via enhancing nuclear factor-kappaB activation. Cell Immunol 264: 114-118.

72. Shadat NM, Koide N, Khuda II, Dagvadorj J, Tumurkhuu G, et al. (2010) Retinoblastoma protein-interacting zinc finger 1 (RIZ1) regulates the proliferation of monocytic leukemia cells via activation of p53. Cancer Invest 28: 806-812

73. Liu ZY, Wang JY, Liu HH, Ma XM, Wang CL, et al. (2013) Retinoblastoma protein-interacting zinc-finger gene 1 (RIZ1) dysregulation in human malignant meningiomas. Oncogene 32: 1216-1222.

74. Ivanov GS, Ivanova T, Kurash J, Ivanov A, Chuikov S, et al. (2007) Methylationacetylation interplay activates p53 in response to DNA damage. Mol Cell Biol 27: 6756-6769.

75. Wang TJ, Huang MS, Hong CY, Tse V, Silverberg GD, et al. (2001) Comparisons of tumor suppressor p53, p21, and p16 gene therapy effects on glioblastoma tumorigenicity in situ. Biochem Biophys Res Commun 287: 173-180.

76. Sun W, Yang J (2010) Functional mechanisms for human tumor suppressors. J Cancer 1: 136-140.

77. Dong JT, Lamb PW, Rinker-Schaeffer CW, Vukanovic J, Ichikawa T, et al. (1995) KAl1, a metastasis suppressor gene for prostate cancer on human chromosome 11p11.2. Science 268: 884-886.

78. Mashimo T, Watabe M, Hirota S, Hosobe S, Miura K, et al. (1998) The expression of the KAl1 gene, a tumor metastasis suppressor, is directly activated by p53. Proc Natl Acad Sci U S A 95: 11307-11311.

79. Zhang XA, He B, Zhou B, Liu L (2003) Requirement of the p130CAS-Crk coupling for metastasis suppressor KAl1/CD82-mediated inhibition of cell migration. J Biol Chem 278: 27319-27328.

80. Congdon LM, Sims JK, Tuzon CT, Rice JC (2014) The PR-Set7 binding domain of Riz1 is required for the H4K20me1-H3K9me1 trans-tail 'histone code' and Riz1 tumor suppressor function. Nucleic Acids Res. 